\title{
Tingkat Keberhasilan Program Peningkatan Fasilitas Ruang Terbuka Hijau (RTH) Terhadap Pemanfaatan Taman Kota di Kecamatan Kota Kabupaten Kudus
}

\section{Aditya Hermawan ${ }^{1}$}

Diterima : Juli 2015

Disetujui : 7 September 2015

\begin{abstract}
The uncontrolable of development in the city has caused the green open area become rare. To fulfill it through Regent Private Constitution number 16 of 2012 and number 102013 The Government of Kudus has been trying to develop facilities of the Green Open Space in form of rehabilitation and development of the town park which scatter in a few districtsin Kudus Regency. The problem is that the program of development in Green Open Space is only review in the physical Development, not in the uses aspect. Those can be proved by the factual conditions on the field that showed of the neglection and started to break down in Krida Wisata Park and Ganesha Park. The research is using accesibility, comfortability, security, visiting reasons, frequent of time, and frequent of visits, and the satisfaction of the visitors according to the available facilities there. According to Tangkilisan (2005) the use of town park can be rate effectives if there is satisfactory shown by the visitors. The visitors satisfaction about the facilities can be measured and concluded whether the program is success or not in the town park. Perceptions and preferences of the visitors can be a valuable addition to build up a dream town park that fits with the society. Eventually the analysis result has given image that the development of facilities program for Krida Wisata Park dan Taman Ganesha didn't run well, this can be caused by inapropriate and inadequates expectation in condition of facilities in town park. Most of the visitors expected to conduct any services to whole in both of Krida Wisata Park, especially in Ganesha Park. Society involvement as an important instrument in the construction must be maintain to escort the development process.
\end{abstract}

Keyword: Green Open Space, TownPark, Program successful, the usage

\begin{abstract}
ABSTRAK
Perkembangan kawasan perkotaan yang tidak terkontrol mengakibatkan terbatasnya Ruang Terbuka Hijau (RTH). Untuk memenuhi hal tersebut melalui Peraturan Bupati Nomor 16 Tahun 2012 dan Nomor 10 Tahun 2013 Pemerintah Kabupaten Kudus mengupayakan peningkatan fasilitas RTH dalam bentuk rehabilitasi serta pembangunan taman kota yang tersebar di beberapa kecamatan di Kabupaten Kudus. Permasalahannya program peningkatan fasilitas RTH hanya melihat aspek pembangunan fisik, bukan aspek pemanfaatan. Hal itu dapat dibuktikan dari beberapa kondisi faktual di lapangan yang menunjukkan bahwa fasilitas yang terdapat di Taman Krida Wisata dan Taman Ganesha tersebut yang tidak terawat dan mulai rusak. Penelitian ini menggunakan variabel aksesbilitas, kenyamanan, keamanan, alasan kunjungan, lama dan frekuensi kunjungan serta tingkat kepuasan pengunjung terhadap fasilitas yang tersedia. Menurut Tangkilisan (2005) pemanfaatan suatu taman kota dapat dikatakan efektif apabila terdapat kepuasan dari penggunanya. Ukuran kepuasan pengunjung terhadap fasilitas kemudian menyimpulkan berhasil atau tidaknya program peningkatan fasilitas RTH di kedua taman kota tersebut. Persepsi dan preferensi pengunjung menjadi nilai tambah untuk membangun konsep taman yang sesuai keinginan dan harapan masyarakat. Pada akhirnya hasil analisa memberikan gambaran bahwa program peningkatan fasilitas di Taman Krida dan Taman Ganesha tidak cukup berhasil, hal itu disebabkan karena kondisi fasilitas yang tidak sesuai dengan harapan pengunjung. Sebagian besar pengunjung mengarapkan dilakukan perbaikan secara menyeluruh baik di Taman Krida Wisata, terutama di Taman Ganesha. Keterlibatan masyarakat sebagai instrumen penting dalam pembangunan harus dipertahankan untuk senantiasa mengawal proses pembangunan.
\end{abstract}

Kata Kunci : Ruang Terbuka Hijau, Taman Kota, Keberhasilan Program, Pemanfaatan

${ }^{1}$ Kementerian Pekerjaan Umum JI. Pattimura No. 20 Kebayoran Baru Jakarta Selatan

Kontak Penulis : dityahermawan@yahoo.co.id 


\section{PENDAHULUAN}

Pertambahan penduduk di kawasan perkotaan yang tidak merata di suatu wilayah menimbulkan banyak masalah. Konsep Kota Hijau yang diusung oleh pemerintah merupakan kewajiban di setiap wilayah untuk menyediakan Ruang Terbuka Hijau (RTH) sebagai syarat pemenuhan dalam pembangunan wilayah perkotaan. Undang - Undang Nomor 26 Tahun 2007 tentang Penataan Ruang mengatur jelas proporsi RTH di wilayah Perkotaan sebesar 30 persen. Salah satu wilayah yang masih rendah proporsi minimal RTH adalah di Kabupaten Kudus. Berdasarkan sumber dari pemkab.go.id tahun 2013, hasil pencapaian standar pemenuhan RTH Kabupaten Kudus hanya mencapai 18 persen. Pemerintah Kabupaten Kudus berupaya meningkatkan RTH melalui program yang terbagi dalam beberapa paket kegiatan. Salah satu wujud peningkatan fasilitas RTH di Kabupaten Kudus dilakukan dengan cara pembangunan taman - taman kota di beberapa wilayah. Khusus untuk Kecamatan Kota, program peningkatan fasilitas RTH diaplikasikan dengan terbangunnya Taman Ganesha dan rehabilitasi Taman Krida Wisata. Kebijakan terkait peningkatan RTH yaitu Peraturan Bupati Nomor 10 Tahun 2012 muncul salah satunya atas dasar menurunnya minat pengunjung dari Taman Krida yaitu dari tahun 2010 - 2011 yaitu 65.333 pengunjung menjadi 54.527 pengunjung (sumber: BPS Kudus, 2011). Beberapa sumber yang lain dari www.radiosuarakudus.com tanggal 20 Agustus 2011, Sulistiyana yang merupakan penanggungjawab Taman Krida Wisata menuturkan bahwa pengunjung Taman Krida Wisata turun drastis, karena kalah saing dengan tempat wisata swasta.

Permasalahan yang terjadi adalah terkait tingkat keberhasilan program peningkatan fasilitas RTH terhadap pemanfaatan taman kota di Kecamatan Kota. Setelah implementasi kebijakan tersebut, muncul beberapa permasalahan terutama berkaitan dengan aspek pemanfaatan yang dilakukan oleh masyarakat sebagai pengunjung. Seperti yang diungkapkan oleh Subekan dalam harian Radar Pekalongan (2014) menyebutkan taman kota di Kudus disalahgunakan para remaja untuk berbuat mesum. Hal ini disebabkan minimnya penerangan serta pengawasan di area taman kota tersebut. Suwoko dan Faisol Hadi juga dalam harian murianews (2014), berpendapat bahwa masyarakat sekitar taman ganesha membuang kotoran sembarangan di lokasi taman, padahal sudah disediakan WC umum. Akibatnya taman ganesha menjadi tidak terawat karena perilaku warga sekitar yang tidak ikut menjaga.

Keterangan :

1. Taman Krida Wisata

2. Taman Ganesha

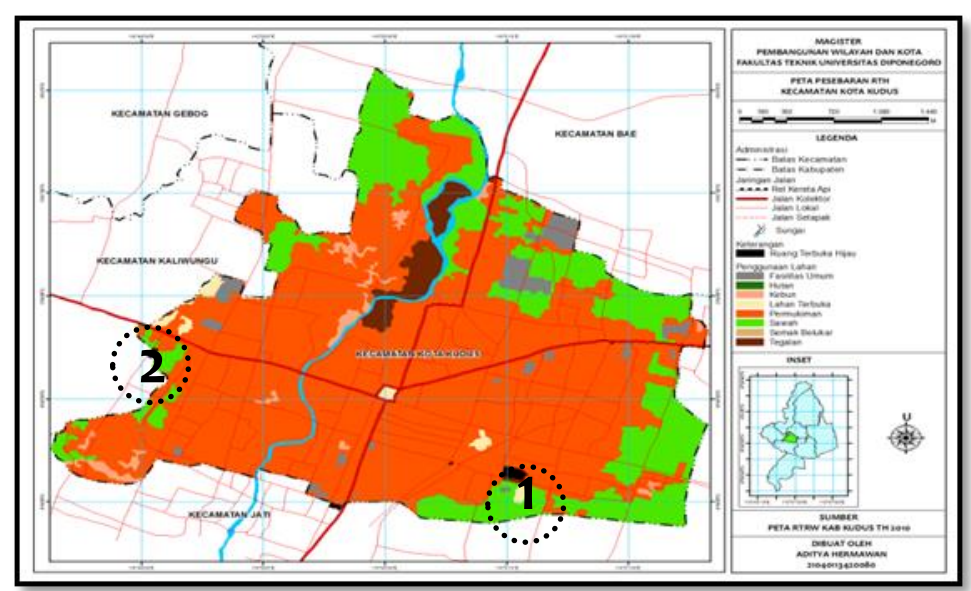

Sumber : Penulis, 2015
GAMBAR 1

PETA KAWASAN PENELITIAN 
Pemerintah Kabupaten Kudus hanya melihat dari aspek pembangunan fisik demi pemenuhan standar minimal persyaratan ketersediaan Ruang Terbuka Hijau (RTH), terutama pembangunan Taman Ganesha. Taman Ganesha merupakan hibah dari Pemerintah Provinsi Jawa Tengah dengan tujuan untuk membantu program peningkatan fasilitas RTH di Kabupaten Kudus. Padahal bila dilihat dari outcome produk kebijakan pemerintah, aspek pemanfaatan merupakan ukuran keberhasilan kinerja pembangunan. Dasar logikanya adalah output dari peningkatan fasilitas Ruang Terbuka Hijau (RTH) ini adalah terbangunnya taman kota di Kecamatan Kota, sedangkan outcomenya adalah banyaknya pengunjung yang dilihat dari besar minat atau ketertarikan masyarakat untuk memanfaatkan fasilitas tersebut. Selanjutnya dapat dirumuskan pertanyaan penelitiannya yaitu "apakah program peningkatan fasilitas RTH yang dinilai dari pemanfaatan taman kota di Kecamatan Kota Kabupaten Kudus sudah berhasil?"

Tujuan dari penelitian untuk menganalisa tingkat keberhasilan program peningkatan fasilitas RTH terhadap pemanfaatan taman kota di Kecamatan Kota Kudus. Selanjutnya dapat diketahui konsep taman kota yang layak dan tepat digunakan di kedua taman yang menjadi obyek penelitian di Kecamatan Kota Kudus. Pada akhirnya program peningkatan fasilitas Ruang Terbuka Hijau (RTH) oleh Pemerintah Daerah di Kecamatan Kota Kabupaten Kudus melalui taman kota dapat dinilai secara tepat dengan melihat aspek pemanfaatannya.

\section{METODE PENELITIAN}

Dalam penelitian ini penulis menggunakan metode deskriptif kuantitatif. Pendekatan penelitian ini menggunakan jenis penelitian studi kasus. Penelitian tentang tingkat keberhasilan program peningkatan fasilitas Ruang Terbuka Hijau (RTH) terhadap pemanfaatan taman kota di Kecamatan Kota menggunakan pengukuran nilai Skala Likert. Bentuk skala likert yang umum digunakan oleh peneliti merupakan pernyataan positif adalah sebagai berikut:
a. Sangat baik
$=$ Bobot nilai 5
b. Baik
$=$ Bobot nilai 4
c. Cukup
$=$ Bobot nilai 3
d. Buruk
$=$ Bobot nilai 2
e. Sangat buruk
$=$ Bobot nilai 1

Rumus yang digunakan untuk mengukur Skala Likert berdasarkan dari jumlah responden, serta besarnya bobot nilai dalam skala. Skor ideal adalah nilai yang digunakan untuk menghitung bobot nilai dalam menentukan skala dan jumlah seluruh jawaban. Rumus yang digunakan yaitu (Sugiyono, 2003):

Dimana :

$$
\text { Skor Ideal }=\text { T } x \text { Pn }
$$

$\mathrm{T} \quad=$ Jumlah Responden

$\mathrm{Pn} \quad=$ Nilai Skala

Sedangkan untuk memperoleh hasil interpretasi dalam bentuk persentase dari besarnya penilaian, menggunakan rumus indeks presentase sebagai berikut :

$$
\text { Indeks } \%=\frac{\text { Jumlah Skor Frekuensi }}{\text { Jumlah Skor Ideal }} x 100
$$


Teknik sampling yang digunakan dalam penelitian ini adalah Accidental Sampling. Teknik accidental sampling adalah teknik menentukan sampel berdasarkan kebetulan, yaitu siapa saja yang secara kebetulan atau insidental bertemu dengan peneliti dapat digunakan sebagai sampel jika orang tersebut dipandang cocok sebagai sumber data (Sugiyono, 2003). Menindaklanjuti dari teknik pengambilan sampling yang bersifat non probability, maka agar jumlah sampling dapat merepresentasikan tujuan penelitian dilakukan survei jumlah rata - rata pengunjung. Sehingga pembagian sampel berdasarkan hasil survei pengunjung yang telah dilakukan masing - masing taman adalah sebagai berikut :

TABEL 1

SURVEI AWAL RESPONDEN DI TAMAN KOTA UNTUK PENENTUAN JUMLAH SAMPEL

\begin{tabular}{|c|l|c|c|c|c|c|c|c|c|c|c|}
\hline \multirow{2}{*}{ No } & \multirow{4}{*}{ Taman Kota } & \multicolumn{4}{|c|}{ Hari Biasa } & \multicolumn{2}{c|}{$\begin{array}{c}\text { Hari } \\
\text { Libur }\end{array}$} & \multicolumn{2}{c|}{ Jumlah Pengunjung } \\
\cline { 3 - 13 } & & h1 & h2 & h3 & h4 & h5 & h6 & h7 & $\begin{array}{c}\text { rata - rata } \\
\text { per minggu }\end{array}$ & $\begin{array}{l}\text { rata - rata } \\
\text { per bulan }\end{array}$ \\
\hline $\mathbf{1}$ & Krida Wisata & 13 & 15 & 12 & 14 & 17 & 16 & 36 & 18 & 70 \\
\hline $\mathbf{2}$ & Ganesha & 9 & 11 & 12 & 10 & 12 & 13 & 20 & 12 & 50 \\
\hline & Total & & & & & & & & 30 & 120 \\
\hline
\end{tabular}

Sumber : Hasil Survei Peneliti, 2015

\section{GAMBARAN UMUM}

Taman Kota di Kecamatan Kota Kudus pada dasarnya sudah banyak yang dibangun. Hal tersebut terlihat dari hampir di setiap pertigaan besar terdapat taman kota meskipun luasnya cukup kecil. Sedangkan kontribusi terhadap peningkatan kapasitas Ruang Terbuka Hijau (RTH) di kawasan perkotaan belum memenuhi standar minimal persyaratan yaitu sebesar 20 persen.

\section{a. Taman Krida Wisata}

Taman Krida Wisata merupakan taman rekreasi keluarga dengan suasana yang asri, sejuk dan teduh karena banyaknya pepohonan di taman tersebut. Taman ini dilengkapi dengan berbagai patung binatang yang menarik dan bersifat edukatif bagi anak-anak, antara lain patung binatang. Selain itu, taman ini dilengkapi dengan gedung terbuka yang representatif

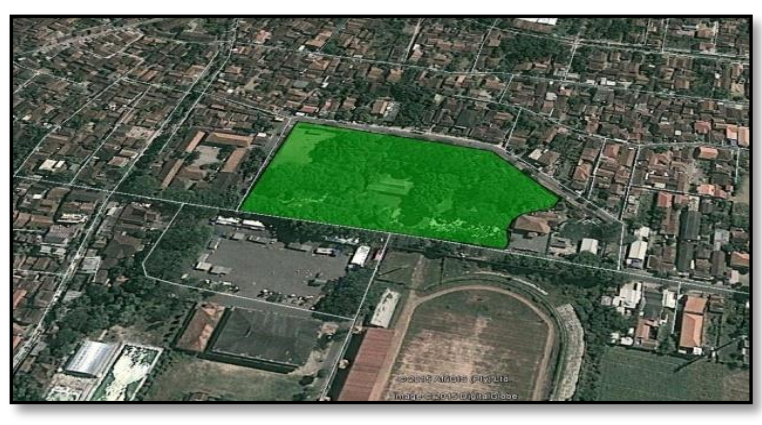

Sumber : Citra Satelit, 2013

GAMBAR 2

\section{GAMBAR CITRA SATELIT TAMAN KRIDA WISATA}



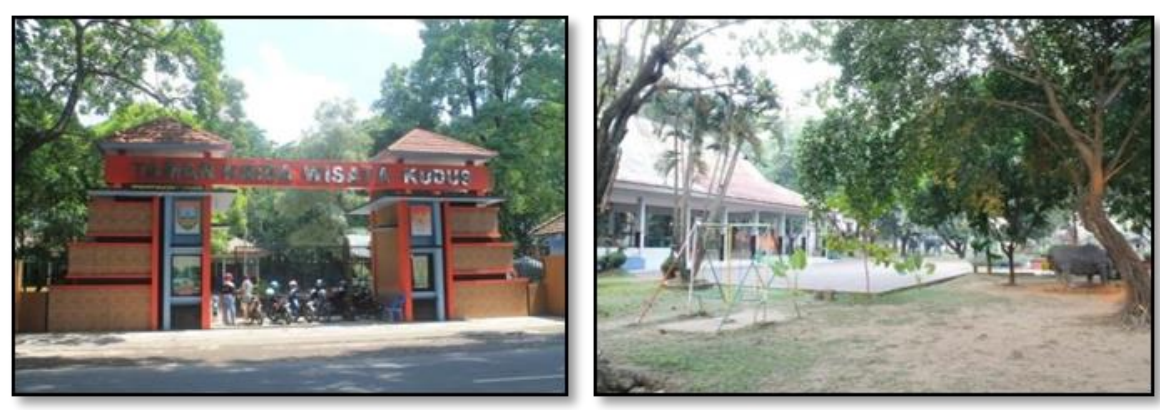

Sumber : Pengamatan langsung, 2014

\section{GAMBAR 3 TAMAN KRIDA WISATA}

\section{b. Taman Ganesha}

Taman Ganesha memiliki luas yang terbangun kurang lebih sekitar $5.000 \mathrm{~m} 2$ dengan potensi perluasan sampai dengan 1 hektar. Fasilitas yang terdapat di Taman Ganesha antara lain adalah bangku taman, tempat melakukan pertunjukan, papan informasi surat kabar, lampu penerangan yang menggunakan teknologi tenaga surya. Selain itu di samping lokasi taman ini terdapat kios - kios tempat berjualan para warga. Sehingga bagi para pengunjung tidak merasa kesulitan untuk mencari makanan ketika berkunjung di Taman Ganesha. Di dalam aera taman juga terdapat pos pengelolaan serta penjagaan fasilitas pertamanan.

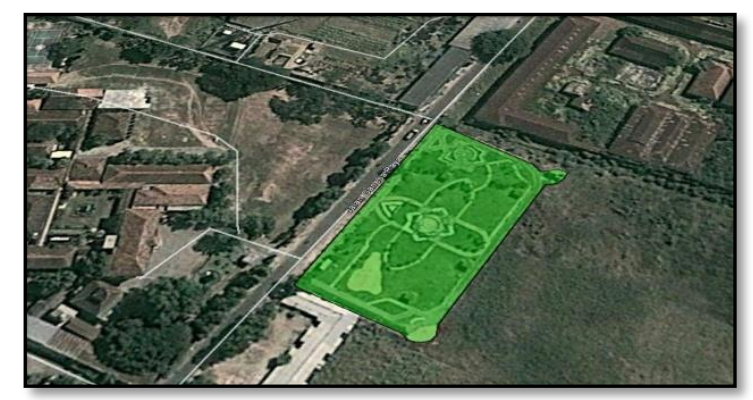

Sumber : Citra Satelit , 2013

\section{GAMBAR 4 \\ GAMBAR CITRA SATELIT TAMAN GANESHA}
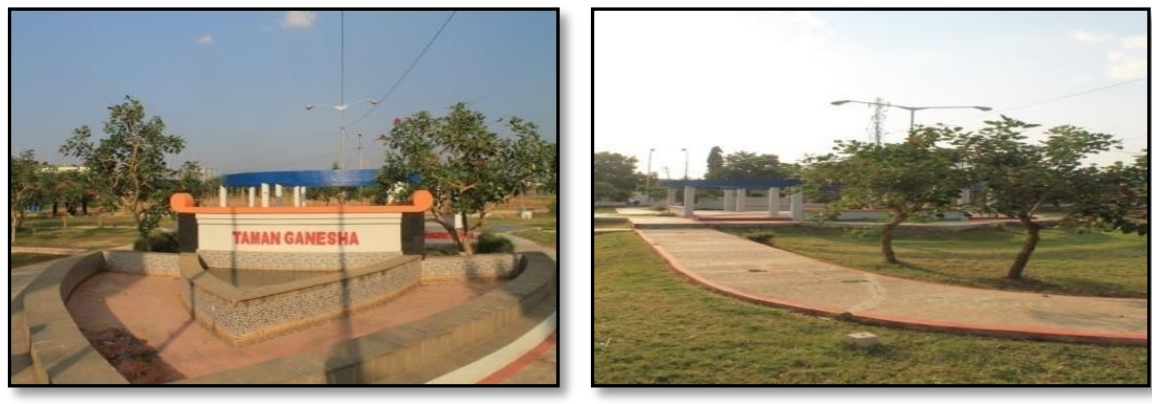

Sumber : Pengamatan langsung, 2014

GAMBAR 5

TAMAN GANESHA 


\section{KAJIAN TEORI}

Menurut Undang - Undang Nomor 26 Tahun 2007 tentang Penataan Ruang Pasal 29 tentang Ruang Terbuka Hijau (RTH) Publik merupakan ruang terbuka hijau yang dimiliki dan dikelola oleh pemerintah daerah kota yang digunakan untuk kepentingan masyarakat secara umum. Yang termasuk RTH publik, salah satu diantara adalah taman kota. Taman Kota sebagai RTH kota adalah bagian dari ruang terbuka (open spaces) suatu wilayah perkotaan yang diisi oleh tumbuhan, tanaman, dan vegetasi (endemik, introduksi) guna mendukung manfaat langsung dan/atau tidak langsung yang dihasilkan oleh RTH dalam kota yaitu keamanan, kenyamanan, kesejahteraan, dan keindahan wilayah perkotaan tersebut (Sukawan, 2012).

Hessel Tangkilisan (2005) berpendapat bahwa ukuran efektivitas pembangunan adalah dari kepuasan pengguna. Menurut Yanuardi (2012) cara mengukur indikator keberhasilan pembangunan perlu ditambah dengan menjadikan masyarakat sebagai subjek dari pembangunan. Kondisi dapat dilakukan dengan memberikan ruang pada masyarakat untuk mengukur keberhasilan pembangunan menurut ukuran mereka sendiri. Terkait dengan peran masyarakat dalam pembangunan, kepuasan masyarakat merupakan faktor yang sangat menentukan bagi keberhasilan penyelenggaraan kepemerintahan (Vyandri, dkk, 2013).

Ukuran tingkat keberhasilan dari peningkatan fasilitas taman kota dilihat dari aspek pemanfaatan yang dinilai dari opini masyarakat sebagai pengunjung. Sebuah taman kota yang betujuan sebagai arena rekreasi warga kota, setidaknya harus menyediakan fasilitas - fasilitas antara lain : pohon, pedestrian, bangku, gazebo, arena bermain, arena olahraga, toilet, saluran air, tempat sampah, lampu taman, tempat parkir, pusat informasi dan pos penjagaan (Guntoro dalam Mukafi, 2013). Sedangkan bila dilihat dari pemanfaatan fasilitas publik maka yang dapat mempengaruhi frekuensi kunjungan ke taman Menurut Brookshire, Ives, dan Schulze dalam Hufschmidt (1987) adalah tingkat pendapatan, biaya perjalanan, tingkat pendidikan, jenis kelamin, jarak tempat tinggal, lama mengetahui keberadaan taman wisata, waktu tempuh, jumlah rombongan dan waktu yang dihabiskan di lokasi.

\section{ANALISIS TINGKAT KEBERHASILAN PROGRAM PENINGKATAN FASILITAS RTH TERHADAP PEMANFAATAN TAMAN KOTA}

\section{a. Identifikasi Taman Kota di Kecamatan Kota}

Hasil analisis menunjukkan berdasarkan Permen PU No. 5 Tahun 2008 dilihat dari luasan area Taman Krida Wisata masuk kategori taman kecamatan, dengan jumlah penduduk Kecamatan Kota sebanyak 92.039 jiwa. Hasil pengukuran luasan menunjukkan bahwa Taman Krida belum memenuhi syarat minimal luasan. Taman Krida Wisata memiliki luas area taman $17.000 \mathrm{~m}^{2}$, sedangkan luas minimal untuk tipe RTH taman kecamatan adalah 24.000 $\mathrm{m}^{2}$. Ketika disandingkan dengan Permen PU maka luasan minimal untuk sebuah taman kota, Taman Krida harus ditambah sampai dengan $144.000 \mathrm{~m}^{2}$. Hal ini membuktikan bahwa secara spasial luasan area Taman Krida Wisata belum memenuhi persyaratan. Sedangkan untuk Taman Ganesha masuk kategori taman kecamatan. Taman Ganesha belum memenuhi syarat minimal untuk pemenuhan luas area taman. Luas Taman Ganesha adalah $5.000 \mathrm{~m}^{2}$, sedangkan untuk syarat minimal luasan taman kecamatan adalah $24.000 \mathrm{~m}^{2}$. Bila dilihat dari lokasi pengelompokan maka letak Taman Ganesha sudah tepat karena masuk ke dalam area sekolah atau dekat dengan pusat aktivitas kecamatan yaitu adanya pasar dan perkantoran. Sedangkan bila disandingkan dengan syarat ketersedian fasilitas taman kota yang diutarakan oleh Guntoro dalam Mukafi (2013), maka Taman Ganesha belum memenuhi kriteria taman kota yang baik. Karena ada beberapa fasilitas yang tidak tersedia dalam area 
taman, antara lain fasilitas olahraga dan area bermain anak.

\section{b. Analisis Karakteristik Pengunjung Taman Kota $\checkmark$ Taman Krida Wisata}

TABEL 3

\section{KARAKTERISTIK PENGUNJUNG TAMAN KRIDA WISATA}

\begin{tabular}{|c|c|c|c|}
\hline No & Variabel & Hasil Olahan Data & Analisa \\
\hline 1 & $\begin{array}{c}\text { Jenis } \\
\text { Kelamin }\end{array}$ & $\begin{array}{l}\text { Sebagian besar pengunjung } \\
\text { berjenis kelamin laki - laki } \\
\text { yaitu sebesar } 66 \% \text {. Secara } \\
\text { psikologis laki - laki tidak } \\
\text { dibekali kemampuan melihat } \\
\text { suatu hal yang rinci dan kurang } \\
\text { perhatian. Akibatnya banyak } \\
\text { fasilitas yang tidak terawat } \\
\text { dan terbengkalai. }\end{array}$ & $\begin{array}{l}\text { Dominasi laki - laki sebagai } \\
\text { pengunjung taman sangat } \\
\text { berpengaruh terhadap baik } \\
\text { buruknya kondisi fasilitas di area } \\
\text { taman. }\end{array}$ \\
\hline 2 & Usia & $\begin{array}{l}\text { Sebagian besar pengunjung } \\
\text { berumur antara } 26-45 \text { tahun } \\
\text { yaitu sebesar } 49 \% \text {. Hal ini } \\
\text { menunjukkan bahwa para } \\
\text { pengunjung taman adalah } \\
\text { dalam rentang usia produktif. } \\
\end{array}$ & $\begin{array}{l}\text { Banyaknya pengunjung dalam } \\
\text { rentang usia produktif } \\
\text { menunjukkan tingginya } \\
\text { kebutuhan para pengunjung } \\
\text { terhadap fasilitas taman sebagai } \\
\text { sarana rekreasi atau tempat rileks }\end{array}$ \\
\hline 3 & Pekerjaan & $\begin{array}{l}\text { Para pengunjung yang } \\
\text { sebagian besar adalah } \\
\text { karyawan/pekerja yaitu } \\
\text { sebesar } 39 \% \text {, dimana } \\
\text { mempunyai kecenderungan } \\
\text { membutuhkan fasilitas sebagai } \\
\text { sarana rekreasi, istirahat dan } \\
\text { santai }\end{array}$ & $\begin{array}{l}\text { Banyaknya pengunjung yang } \\
\text { merupakan karyawan } \\
\text { menunjukkan tingginya } \\
\text { kebutuhan para pengunjung } \\
\text { terhadap fasilitas taman sebagai } \\
\text { sarana rekreasi atau tempat rileks }\end{array}$ \\
\hline 4 & Pendidikan & $\begin{array}{l}\text { Pengunjung sebagian besar } \\
\text { adalah tamatan SMA/sederajat } \\
\text { dengan pendidikan relatif } \\
\text { tinggi bagi penduduk } \\
\text { Kecamatan Kota yaitu sebesar } \\
48 \% . \text { Hal ini membuktikan } \\
\text { kebutuhan pengunjung } \\
\text { terhadap fasilitas yang } \\
\text { tersedia di taman cukup baik }\end{array}$ & $\begin{array}{l}\text { Semakin tinggi tingkat pendidikan } \\
\text { berpengaruh terhadap tingginya } \\
\text { kebutuhan penggunaan dan } \\
\text { pemanfaatan fasilitas. }\end{array}$ \\
\hline 5 & Pendapatan & $\begin{array}{l}\text { Para pengunjung mayoritas } \\
\text { memiliki pendapatan dibawah } \\
\text { UMR yaitu sebesar } \\
\text { Rp.1.000.000 sebanyak 29\%, } \\
\text { hal ini menunjukkan bahwa } \\
\text { rendahnya pendapatan } \\
\text { pengunjung tidak } \\
\text { berpengaruh terhadap }\end{array}$ & $\begin{array}{l}\text { Semakin rendah pendapatan tidak } \\
\text { berpengaruh terhadap } \\
\text { kemampuan daya beli penduduk } \\
\text { untuk memperoleh pelayanan } \\
\text { fasilitas. }\end{array}$ \\
\hline
\end{tabular}




\begin{tabular}{|l|l|l|l|}
\hline & & $\begin{array}{l}\text { kebutuhan pengunjung untuk } \\
\text { menikmati fasilitas taman }\end{array}$ & \\
\hline
\end{tabular}

Sumber: Hasil Analisa, 2015

\section{Taman Ganesha}

TABEL 4

KARAKTERISTIK PENGUNJUNG TAMAN GANESHA

\begin{tabular}{|c|c|c|c|}
\hline No & Variabel & Hasil Olahan Data & Analisa \\
\hline 1 & $\begin{array}{l}\text { Jenis } \\
\text { Kelamin }\end{array}$ & $\begin{array}{l}\text { Mayoritas pengunjung kaum laki - } \\
\text { laki yaitu sebesar } 68 \% \text {. }\end{array}$ & $\begin{array}{l}\text { Dominasi laki }- \text { laki sebagai } \\
\text { pengunjung taman berpengaruh } \\
\text { terhadap baik buruknya kondisi } \\
\text { fasilitas di area taman. }\end{array}$ \\
\hline 2 & Usia & $\begin{array}{l}\text { Sebagian besar pengunjung } \\
\text { berumur antara } 26-45 \text { tahun } \\
\text { yaitu sebesar } 48 \% \text { Hal ini } \\
\text { menunjukkan bahwa para } \\
\text { pengunjung taman adalah dalam } \\
\text { rentang usia produktif. }\end{array}$ & $\begin{array}{l}\text { Banyaknya pengunjung dalam } \\
\text { rentang usia produktif menunjukkan } \\
\text { tingginya kebutuhan pengunjung } \\
\text { terhadap fasilitas taman sebagai } \\
\text { sarana rekreasi atau tempat rileks }\end{array}$ \\
\hline 3 & Pekerjaan & $\begin{array}{l}\text { Para pengunjung yang sebagian } \\
\text { besar adalah karyawan/pekerja } \\
\text { yaitu sebesar } 32 \% \text {, dimana } \\
\text { mempunyai kecenderungan } \\
\text { membutuhkan fasilitas sebagai } \\
\text { sarana rekreasi, istirahat dan } \\
\text { santai }\end{array}$ & $\begin{array}{l}\text { Banyaknya pengunjung yang } \\
\text { merupakan karyawan menunjukkan } \\
\text { tingginya kebutuhan pengunjung } \\
\text { terhadap fasilitas taman sebagai } \\
\text { sarana rekreasi atau tempat rileks }\end{array}$ \\
\hline 4 & Pendidikan & $\begin{array}{l}\text { Pengunjung sebagian besar } \\
\text { adalah tamatan SMP/sederajat } \\
\text { dengan pendidikan relatif rendah } \\
\text { bagi penduduk Kecamatan Kota } \\
\text { yaitu sebesar } 38 \% \text { Hal ini } \\
\text { membuktikan kebutuhan } \\
\text { pengunjung terhadap fasilitas } \\
\text { yang tersedia di taman sangat } \\
\text { kurang }\end{array}$ & $\begin{array}{l}\text { Semakin tinggi tingkat pendidikan } \\
\text { berpengaruh terhadap tingginya } \\
\text { kebutuhan penggunaan dan } \\
\text { pemanfaatan fasilitas. }\end{array}$ \\
\hline 5 & Pendapatan & $\begin{array}{l}\text { Para pengunjung mayoritas } \\
\text { memiliki pendapatan dibawah } \\
\text { UMR yaitu sebesar Rp.1.000.000 } \\
\text { sebanyak } 29 \% \text {, hal ini menunjukkan } \\
\text { bahwa rendahnya pendapatan } \\
\text { pengunjung tidak berpengaruh } \\
\text { terhadap kebutuhan pengunjung } \\
\text { untuk menikmati fasilitas taman }\end{array}$ & $\begin{array}{l}\text { Semakin rendah pendapatan tidak } \\
\text { berpengaruh terhadap kemampuan } \\
\text { daya beli penduduk untuk } \\
\text { memperoleh pelayanan fasilitas. }\end{array}$ \\
\hline
\end{tabular}

Sumber : Hasil Analisa, 2015 


\section{c. Analisis Tingkat Keberhasilan Program Peningkatan Fasilitas terhadap Pemanfaatan Taman Kota}

\section{$\checkmark$ Taman Krida Wisata}

Hasil analisa terhadap tingkat kenyamanan menunjukkan bahwa sebagian besar pengunjung merasa nyaman ketika berada di Taman Krida Wisata yaitu sebesar $83 \%$, dengan hasil pengukuran skala likert dengan predikat cukup baik. Faktor kenyamanan dipengaruhi oleh suasana di sekitar taman. Dengan tingkat keamanan pengunjung sebesar $81 \%$ merasa aman ketika berada di taman. Faktor keamanan dipengaruhi oleh keberadaan petugas keamanan. Hasil pengukuran skala likert terhadap tingkat keamanan para pengunjung menunjukkan predikat cukup baik. Analisas aksesblitas sebagian besar Pengunjung menempuh jarak $500 \mathrm{~m}-2 \mathrm{~km}$ dengan waktu tempuh $10-$ 30 menit, hal itu menunjukkan bahwa sebagian besar pengunjung adalah warga Kecamatan Kota. Sebagian besar pengunjung beralasan untuk aktivitas rekreasi yaitu sebesar 50\%, dan sebagian besar juga enggan berkunjung karena alasan jarak yang jauh sebesar 29\%. Frekuensi dan lama kunjungan rata - rata pengunjung menghabiskan waktu berkunjung antara 30 menit - 1 jam dengan frekuensi kunjungan selama 1 minggu sekali. Sehingga dapat disimpulkan bahwa pengunjung cukup betah berada di area Taman Krida Wisata dengan frekuensi kunjungan yang cukup sering. Sedangkan untuk tingkat kepuasan terhadap fasilitas dapat dilihat pada tabel berikut :

TABEL 5

\section{TINGKAT KEPUASAN PENGUNJUNG TERHADAP FASILITAS DI TAMAN KRIDA WISATA}

\begin{tabular}{|c|c|c|c|c|}
\hline \multirow{2}{*}{ No } & \multirow{2}{*}{ Fasilitas } & \multicolumn{2}{|c|}{ Tingkat Kepuasan (\%) } & \multirow{2}{*}{$\begin{array}{c}\text { Total } \\
\text { (\%) }\end{array}$} \\
\hline & & Puas (\%) & Tidak Puas (\%) & \\
\hline 1 & Pos Keamanan & 51 & 49 & 100 \\
\hline 2 & Tempat Sampah & 66 & 34 & 100 \\
\hline 3 & Media/ Panggung & 50 & 50 & 100 \\
\hline 4 & Jalur Pedestrian & 71 & 29 & 100 \\
\hline 5 & Tempat Olahraga & 59 & 41 & 100 \\
\hline 6 & Tempat/ Alat Bermain & 76 & 24 & 100 \\
\hline 7 & Bangku Taman & 57 & 43 & 100 \\
\hline 8 & Lampu Penerangan & 51 & 49 & 100 \\
\hline 9 & Vegetasi/ Pohon Peneduh & 74 & 26 & 100 \\
\hline 10 & Penanda/ Papan Informasi & 50 & 50 & 100 \\
\hline 11 & Tempat Parkir & 44 & 56 & 100 \\
\hline
\end{tabular}

Sumber : Hasil Analisa, 2015

\section{$\checkmark$ Taman Ganesha}

Hasil analisa terhadap tingkat kenyamanan menunjukkan bahwa sebagian besar pengunjung merasa tidak nyaman ketika berada di Taman Ganesha yaitu sebesar 60\%, dengan hasil pengukuran skala likert dengan predikat buruk. Faktor kenyamanan tidak dipengaruhi oleh suasana di sekitar taman. Sebagian besar pengunjung merasa tidak aman ketika berada di taman yaitu sebesar $84 \%$. Faktor keamanan dipengaruhi oleh lokasi taman yang dekat permukiman penduduk. Hasil pengukuran skala likert terhadap tingkat keamanan para pengunjung menunjukkan predikat buruk. Analisas aksesblitas sebagian besar Pengunjung menempuh jarak $500 \mathrm{~m}-2 \mathrm{~km}$ dengan waktu tempuh $10-$ 30 menit, hal itu menunjukkan bahwa sebagian besar pengunjung adalah warga Kecamatan Kota. Sebagian besar pengunjung beralasan untuk aktivitas rekreasi yaitu sebesar $64 \%$, dan sebagian besar juga enggan berkunjung karena lokasi aman kurang 
aman sebesar 34\%. Frekuensi dan lama kunjungan rata - rata pengunjung menghabiskan waktu berkunjung antara 10 - 30 menit dengan frekuensi kunjungan selama 1 minggu sekali. Sehingga dapat disimpulkan bahwa pengunjung tidak betah berada di area Taman Krida Wisata dengan frekuensi kunjungan yang cukup sering. Sedangkan untuk tingkat kepuasan terhadap fasilitas dapat dilihat pada tabel berikut :

TABEL 6

TINGKAT KEPUASAN PENGUNJUNG TERHADAP FASILITAS DI TAMAN GANESHA

\begin{tabular}{|c|l|c|c|c|}
\hline \multirow{2}{*}{ No } & \multirow{2}{*}{ Fasilitas } & \multicolumn{2}{|c|}{ Tingkat Kepuasan (\%) } & \multirow{2}{*}{$\begin{array}{c}\text { Total } \\
(\%)\end{array}$} \\
\cline { 3 - 4 } & & Puas (\%) & Tidak Puas (\%) & 100 \\
\hline 1 & Pos Keamanan & 6 & 94 & 100 \\
\hline 2 & Tempat Sampah & 54 & 46 & 100 \\
\hline 3 & Media/ Panggung & 46 & 54 & 100 \\
\hline 4 & Jalur Pedestrian & 72 & 28 & 100 \\
\hline 5 & Tempat Olahraga & 14 & 86 & 100 \\
\hline 6 & Tempat/ Alat Bermain & 52 & 48 & 100 \\
\hline 7 & Bangku Taman & 44 & 56 & 100 \\
\hline 8 & Lampu Penerangan & 28 & 72 & 100 \\
\hline 9 & Vegetasi/ Pohon Peneduh & 52 & 48 & 100 \\
\hline 10 & Penanda/Papan Informasi & 41 & 59 & 100 \\
\hline 11 & Tempat Parkir & 19 & 81 & \\
Sumber: Hasil Analisa, 2015 & & & \\
\hline
\end{tabular}

Berdasarkan hasil analisa di atas maka dapat diketahui konsep taman kota yang sesuai keinginan masyarakat. Untuk Taman Krida Wisata Para pengunjung di Taman Krida Wisata menginginkan tersedianya lahan parkir dan perbaikan fasilitas umum yang sudah ada. Sedangkan untuk Taman Ganesha Sehubungan dengan rendahnya tingkat kepuasan dan tingkat keamanan di Taman Ganesha maka sudah selayaknya pengunjung mengharapkan disediakan pos penjaga keamanan serta peningkatan fasilitas baik penambahan maupun perbaikan untuk meningkatkan efektivitas pemanfaatan di Taman Ganesha.

\section{KESIMPULAN}

Taman Krida Wisata dan Taman Ganesha merupakan contoh taman kota aktif di Kecamatan Kota yang memerlukan perhatian tidak hanya secara fisik. Hasil penelitian yang menyebutkan bahwa masih banyak fasilitas di kedua taman kota tersebut yang harus diperhatikan dan diperbaiki sesuai dengan kebutuhan. Taman Krida Wisata perlu ditindaklanjuti, sehubungan sebagai sarana rekreasi dan olahraga di pusat kota. Masih banyak kekurangan terutama fasilitas yang minim perawatan dan rusak. Sedangkan Taman Ganesha, sebagian besar menyatakan bahwa fasilitas yang terdapat di taman tersebut tidak memadai. Bahkan untuk aspek kenyamanan dan keamanan masih dinilai kurang, seperti tidak adanya petugas keamanan dan fasilitas yang mulai rusak. Akibatnya muncul kegiatan - kegiatan negatif yang dilakukan beberapa pengunjung, yang justru semakin merusak tujuan dari dibangunnya Taman Ganesha. 


\section{DAFTAR PUSTAKA}

Adisasmita, Rahardjo. 2012. Analisis Tata Ruang Pembangunan. Yogyakarta : Graha Ilmu.

Darmawan, Edy. 2009. Ruang Publik Dalam Arsitektur Kota. Semarang: Badan Penerbit Universitas Diponegoro.

Hufschmidt, $M$ et.al. 1987. Lingkungan, Sistem Alami dan Pembangunan (Pedoman Penilaian Ekonomis). Yogyakarta : Gajahmada University Press.

Mukafi, Achmad. 2013. Tingkat Ketersediaan Ruang Tebuka Hijau Publik di Kota Kudus. Skripsi. Universitas Negeri Semarang.

Nogi, Hessel ST. 2005. Manajemen Publik. Jakarta : Grasindo.

Nurdiansyah, Ferlina, dkk. 2012. Strategi Peningkatan dan Penyediaan RTH Privat Rumah Tinggal di Kawasan perkotaan. Jurnal EKOSAINS Vol. IV Nomor 3 Bulan November 2012.

Peraturan Daerah Kabupaten Kudus Nomor 16 Tahun 2012 tentang RTRW Kabupaten Kudus Tahun $2012-2032$.

Sunu, Retno, dkk. 2014. Penguatan Governance dan Kelembagaan dalam Meningkatkan Daya Saing Bangsa. Semarang : Badan Penerbit Undip.

Undang - Undang Nomor 26 Tahun 2007 tentang Penataan Ruang.

Yanuardi. 2012. Teori Pembangunan. Diktat: UNY. 